\title{
Shifts in the abundance and community structure of soil ammonia oxidizers in a wet sclerophyll forest under long-term prescribed burning
}

\author{
Xi-En Long a,b, Chengrong Chen ${ }^{\mathrm{a}, *}$, Zhihong Xu ${ }^{\mathrm{c}}$, Ji-zheng He ${ }^{\mathrm{c}, \mathrm{d}, *}$ \\ a Environmental Futures Centre and Griffith School of Environment, Griffith University, Nathan, Brisbane, QLD 4111, Australia \\ ${ }^{\mathrm{b}}$ Key Laboratory of Urban Environment and Health, Institute of Urban Environment, Chinese Academy of Sciences, Xiamen 361021, China \\ c Environmental Futures Centre and School of Biomolecular and Physical Sciences, Griffith University, Nathan, Brisbane, QLD 4111, Australia \\ d State Key Laboratory of Urban and Regional Ecology, Research Centre for Eco-Environmental Sciences, Chinese Academy of Sciences, Beijing 100085, China
}

\section{H I G H L I G H T S}

- We examined how fires affected the abundances and communities of soil AOB and AOA.

- A long-term repeated forest fire experiment was investigated.

- Fires increased the abundance of bacterium $a m o A$ genes, but not archaeal amoA genes.

- Fire also modified the composition of $\mathrm{AOA}$ and $\mathrm{AOB}$ communities.

- AOB genotype was affected by soil pH and DOC, while AOA by nitrate-N and DOC.

\section{A R T I C L E I N F O}

\section{Article history:}

Received 19 June 2013

Received in revised form 6 October 2013

Accepted 6 October 2013

Available online 26 October 2013

Editor: Charlotte Poschenrieder

\section{Keywords:}

Ammonia-oxidizing bacteria

Ammonia-oxidizing archaea

Abundance

Community composition

Prescribed burning

Nitrification

\begin{abstract}
A B S T R A C T
Fire shapes global biome distribution and promotes the terrestrial biogeochemical cycles. Ammonia-oxidizing bacteria $(\mathrm{AOB})$ and archaea $(\mathrm{AOA})$ play a vital role in the biogeochemical cycling of nitrogen $(\mathrm{N})$. However, behaviors of $A O B$ and $A O A$ under long-term prescribed burning remain unclear. This study was to examine how fire affected the abundances and communities of soil AOB and AOA. A long-term repeated forest fire experiment with three burning treatments (never burnt, B0; biennially burnt, B2; and quadrennially burnt, B4) was used in this study. The abundances and community structure of soil AOB and AOA were determined using quantitative PCR, restriction fragment length polymorphism and clone library. More frequent fires (B2) increased the abundance of bacterium amoA gene, but tended to decrease archaeal amoA genes. Fire also modified the composition of AOA and AOB communities. Canonical correspondence analysis showed soil pH and dissolved organic C (DOC) strongly affected AOB genotypes, while nitrate-N and DOC shaped the AOA distribution. The increased abundance of bacterium $a m o A$ gene by fires may imply an important role of $A O B$ in nitrification in fire-affected soils. The fire-induced shift in the community composition of AOB and AOA demonstrates that fire can disturb nutrient cycles.
\end{abstract}

(c) 2013 Elsevier B.V. All rights reserved.

\section{Introduction}

Fire markedly modifies much of the Earth's land surface and terrestrial biogeochemical cycles (Matson et al., 2011; Orians and Milewski, 2007). It has been predicted the frequency and intensity of wildfire would increase under global warming (Bradstock, 2002; Cary, 2002; Westerling et al., 2006). Fire influences the population and species diversity of the aboveground plants (Bond and Van Wilgen, 1996) and belowground soil properties (Certini, 2005) as well as microorganisms (Vázquez et al., 1993). Niboyet et al. (2011) found that fires increased soil nitrous oxide emission when interacting with other factors, such as elevated $\mathrm{CO}_{2}$, precipitation and $\mathrm{N}$ deposition.

\footnotetext{
* Corresponding authors. Tel.: +61 7373 57494; fax: +61 737357459.

E-mail address: c.chen@griffith.edu.au (C. Chen).
}

Being the greatest diverse organisms in terrestrial ecosystems, soil microorganisms are dominant drivers of global nutrient cycles (Fuhrman, 2009). However, effects of fire on abundance and diversity of nitrifiers remain poorly understood (Neary et al., 1999).

Lithoautotrophic ammonia-oxidizing bacteria $(\mathrm{AOB})$, which gain energy from oxidation of ammonia to nitrite, have been considered as the only contributor to aerobic ammonia oxidation before isolating autotrophic ammonia-oxidizing archaea (AOA) from the marine environment (Könneke et al., 2005). Comprehensive studies have indicated AOA seemingly played a more important role than AOB in the global $\mathrm{N}$ cycling. It has been found that AOA widely occurred in freshwater and marine habitats (Caffrey et al., 2007; Francis et al., 2005; Herrmann et al., 2008), various soils and sediments (Di et al., 2009; He et al., 2007; Long et al., 2012; Sahan and Muyzer, 2008), as well as man-made environments (De Vet et al., 2009; Urakawa et al., 
2008; Zhang et al., 2011). Evidence from 12 pristine and agricultural soils in three climatic zones suggested that AOA is the dominant ammonia oxidizer in soils (Leininger et al., 2006). It has been reported that microbial biomass and the proportion of AOB decreased in fireimpacted soils in comparison with unburned sites (Yeager et al., 2005). However, most studies to date have focused mainly on the impacts of fires on belowground ecosystems for single or few burn events. Few long-term studies have been conducted to evaluate the impacts of repeated burnings on ecosystems, while the impacts of repeated fires on soil AOA have not been reported yet.

A previous study in the same wet sclerophyll forest has shown that microbial biomass of soil fungi and bacteria significantly decreased in the biennially burnt plots (Campbell et al., 2008). Meanwhile, Bastias et al. (2006a, b) found that the biennially burnt treatments shifted the community composition of ectomycorrhizal fungi substantially. In this study, we examined the effect of long-term repeated prescribed burning on abundances and communities of soil AOB and AOA.

\section{Materials and methods}

\subsection{Field site description and soil sampling}

The prescribed burning experiment was conducted in the Peachester State Forest (south-eastern Queensland, Australia) $\left(26^{\circ} 50^{\prime} \mathrm{S}, 152^{\circ} 53^{\prime} \mathrm{E}\right.$ ), a typical wet sclerophyll forest dominated by Eucalyptus pilularis Smith with other canopy species including Corymbia intermedia, Eucalyptus microcorys, Eucalyptus resinifera, Syncarpia glomulifera and Lophostemon confertus. Peachester State Forest has a sub-tropical climate with an average annual rainfall of $1711 \mathrm{~mm}$. The long-term experiment was established in 1972, including three treatments: biennially burnt (designated as B2), quadrennial burnt (designated as B4) and never burnt (control plots, designated as B0). Prescribed fires are carried out in the winter and are generally of low intensity $\left(<2500 \mathrm{~kW} \mathrm{~m}^{-1}\right)$. No artificial and natural factors have been applied since the establishment of the burning experiment. There were four replicates for each treatment, and total 12 plots ( $30 \mathrm{~m} 27 \mathrm{~m}$ ) were randomly arranged in the experimental sites. Soils are red to yellow Kandosols (Isbell, 2002), deep sandy and highly permeable with acidic to neutral pH. Further details of the site can be found in previous publications (e.g. Guinto et al., 2001). Soil samples were collected using a $7 \mathrm{~cm}$ diameter corer and at two depths (topsoil $(0-10 \mathrm{~cm})$ and subsoil $(10-20 \mathrm{~cm})$ ). A total of 15 cores were randomly taken from each plot and bulked as one composite sample in June 2005 and July 2010, respectively. All soils were sieved through a $2.0-\mathrm{mm}$ sieve to remove large organic debris and a proportion of subsamples (ca. $50 \mathrm{~g}$ ) were stored at $-80^{\circ} \mathrm{C}$ prior to DNA extraction, while the remaining samples were kept at $4{ }^{\circ} \mathrm{C}$ prior to chemical and biological analyses.

\subsection{Analysis of soil properties}

Soil dissolved organic C (DOC) and N (DON) were measured in $2 \mathrm{M}$ $\mathrm{KCl}$ extracts as described by Chen et al. (2005). In brief, soil DOC and DON were measured by extracting $5.0 \mathrm{~g}$ (dry weight equivalent) of airdried soil with $50 \mathrm{ml}$ of $2 \mathrm{M} \mathrm{KCl}$, shaking on an end-to-end shaker for $1 \mathrm{~h}$ and filtering through a Whatman 42 paper followed by a $0.45 \mu \mathrm{m}$ membrane. The DOC and total soluble N (TSN) concentrations in the filtrates were determined using SHIMADZU TOC-VCPH/CPN analyzer (fitted with a TN unit). Concentrations of $\mathrm{NH}_{4}^{+}-\mathrm{N}$ and $\mathrm{NO}_{3}^{-}-\mathrm{N}$ were determined using the LACHAT Quickchem Automated Ion Analyzer (QuikChem Method 10-107-06-04-D for $\mathrm{NH}_{4}^{+}-\mathrm{N}$ and QuikChem Method 12- 107-04-1-B for $\left.\mathrm{NO}_{3}^{-}-\mathrm{N}\right)$. The DON in the extracts was calculated as the difference between TSN and the sum of $\mathrm{NH}_{4}^{+}-\mathrm{N}$ and $\mathrm{NO}_{3}^{-}-\mathrm{N}$. Soil $\mathrm{pH}$ was determined in 1:5 ( $\mathrm{v} / \mathrm{v})$ soil/water extracts using a combination glass electrode. Soil total $\mathrm{C}$ and $\mathrm{N}$ were determined using an isotope ratio mass spectrometer with a Eurovector Elemental Analyzer (IsoprimeEuroEA 3000, Milan, Italy). Microbial biomass C (MBC) and N (MBN) were determined by a chloroform fumigation extraction method using an EC factor of 2.64 (Vance et al., 1987) and an EN factor of 2.22 (Jenkinson, 1988), respectively.

\subsection{Soil DNA extraction and $P C R$}

Total genomic DNA was extracted from $0.3 \mathrm{~g}$ of soil using the MoBio Powersoil DNA Isolation Kit (Carlsbad, USA). The DNA extracts were qualified using a NanoDrop-2000 UV-vis Spectrophotometer (Thermo Scientific) at $260 \mathrm{~nm}$ and ratios of $A_{260} / A_{230}$ and $A_{260} / A_{280}$ were above 1.4 and 1.7, respectively. The DNA extracts were stored at $-20{ }^{\circ} \mathrm{C}$ prior to further analysis. The negative effects of inhibitors from the soil were tested using a dilution series of 10-, 20- and 50-fold of the extracted DNA in the presence and absence of bovine serum albumin (BSA). A 10-fold dilution plus BSA addition decreased the negative effect of PCR inhibitors to minimum. Primer pairs amoA1F (GGG GTT TCT ACT GGT GGT)/amoA2R (CCC CTC KGS AAA GCC TTC TTC) and CrenamoA23F (ATG GTC TGG CTW AGA CG)/CrenamoA616R (GCC ATC CAT CTG TAT GTC CA) were used to amplify bacterial and archaeal amoA genes, respectively (Tourna et al., 2008). The PCR reaction $(50 \mu \mathrm{L})$ contained $10 \mu \mathrm{L} 5 \times$ GoTaq Flexi Green Buffer (Promega), $2.5 \mathrm{mM} \mathrm{MgCl}_{2}, 750 \mu \mathrm{M}$ each dNTP, $100 \mu \mathrm{M}$ each primer, 1.25 units GoTaq DNA polymerase (Promega), $0.5 \mu \mathrm{L}$ template DNA and ultraclean water to volume. The fragment length of the PCR products was 491 and $629 \mathrm{bp}$ for AOB and AOA, respectively.

\subsection{Bacterial and archaeal amoA gene clone library construction and their genotype identification}

In this study, we only examined the diversities of $A O B$ and $A O A$ of the soil samples collected in 2005. The amoA gene amplicons were purified using a QIAquick Gel Extraction Kit (Qiagen, Valencia, CA) and cloned into the pGEM-T Easy Vector System. The ligation products were used to transform JM109 Competent Cells (Promega, Madison, WI). Twentyfour amoA gene clone libraries were established for AOB and AOA, respectively. For each clone library, approximately 70 transformed clones were randomly obtained and screened with T7/Sp6 primers. The restriction fragment length polymorphism (RFLP) was used to assign amoA genotypes. The RFLP analysis of $a m o A$ gene amplicons was carried out by digesting AOA with the restriction endonuclease MboI (NEB) and HaeIII (NEB) and AOB with and MboI (NEB). Five microliter digested products were loaded on a $3 \%$ agarose gel, running at $100 \mathrm{~V}$ in $1 \times \mathrm{TAE}$ buffer for $60 \mathrm{~min}$ and digitally photographed using ChemiDoc XRS imaging system (Bio-Rad). Digested amoA gene fragment patterns were detected using the Quantity-One software (Bio-Rad). Triplicate representative genotypes from the clone libraries were selected for sequencing (3130x1 Genetic Analyzer, Applied Biosystems). Clone library rarefaction curve analysis with $95 \%$ confidence intervals was calculated using software EstimateS v8.2 (Colwell, 2009). Sequences were deposited in GenBank under accession numbers JF520841JF520989 for AOA and JF520990-JF521023 for AOB.

\subsection{Quantitative PCR analyses of $16 S$ rRNA genes and amoA genes of bacteria and archaea}

The population sizes of microbial genes were determined using quantitative PCR (Mastercycler thermocycler, Eppendorf) by monitoring the SYBR Green I fluorescence. The transformed plasmid DNA was extracted and their concentrations were measured with a NanoDrop 2000 UV-vis Spectrophotometer (Thermo Scientific). Q-PCR standard curves were generated in duplicate with eight serial 10-fold dilutions of the transformed environmental sample plasmid DNA. Plasmid DNA extracted from clone 05PC-A01-03 (JF520842) and 05PC01-60 (JF520991) was used for AOA and AOB Q-PCR standard curve, respectively. The Q-PCR reaction system comprised $10 \mu \mathrm{L}$ SYBR Premix Ex Taq (Perfect Real Time) (Takara Bio), $200 \mu \mathrm{M}$ of each primer, $2 \mu \mathrm{L}$ of 
template DNA and ultraclean water to $20 \mu \mathrm{L}$ volume. Bacterial primer pairs 338f (ACT CCT ACG GGA GGC AG)/518r (ATT ACC GCG GCT GCT GG) and archaeal primer pairs A109f (ACK GCT CAG TAA CAC GT)/ A334r (TCG CGC CTG CTG CTC CCC GT) were used to perform the Q-PCR (Sun et al., 2009). Q-PCR cycling for the bacterial 16S rRNA gene was used with the following conditions: $95^{\circ} \mathrm{C}$ for $2 \mathrm{~min} ; 40$ cycles of $95{ }^{\circ} \mathrm{C}$ for $20 \mathrm{~s}, 55^{\circ} \mathrm{C}$ for $15 \mathrm{~s}, 72^{\circ} \mathrm{C}$ for $30 \mathrm{~s}, 80^{\circ} \mathrm{C}$ for $20 \mathrm{~s}$; and final extension at $72{ }^{\circ} \mathrm{C}$ for $60 \mathrm{~s}$, followed by a default melting curve cycle. Only the annealing temperature was increased to $57^{\circ} \mathrm{C}$ for archaeal 16S rRNA gene Q-PCR protocol. Primer pairs for amoA genotype identification were also used to perform the Q-PCR as above. The thermal protocol for the amoA gene Q-PCR was the same as in the previous publication (Long et al., 2012). The generated standard curve had a slope of -3.3 , a correlation coefficient $>0.999$, and amplification efficiency $>0.94$. Q-PCR was carried out for soil samples both collected in 2005 and 2010.

\subsection{Statistical and phylogenetic analysis}

The differences of soil chemical, biochemical properties and microbial community size under the three prescribed burning regimes and two soil sampling depths were assessed by analysis of variance (ANOVA) with SPSS 18.0. Correlations between soil properties and the abundance of microbial community were analyzed using the Pearson correlation test. All variables showed either a normal or log-normal data distribution with Shapiro-Wilk W test. Least significant difference (LSD) and Dunnet's T3 tests were performed for the homogeneous and non-homogeneous variance, respectively, according to the test of homogeneity of variances. Molecular variance analyses of amoA genes based on the RFLP genotypes were performed using Arlequin 3.5 (Excoffier and Lischer, 2010). We evaluated the frequency and distribution of the haplotypes using 1000 permutations. The effects of soil properties and prescribed burning on the amoA genotypes distribution were analyzed by canonical correspondence analysis (CCA) using the community ecology package 'vegan' (Oksanen et al., 2010). The standard R function STEP was used to select environmental variables with Akaike's information criterion (AIC). Canonical correspondence analysis (CCA) ordination diagrams were performed using 1000 times permutation tests and $p$-values $\leq$ 0.05 was considered statistically significant. The phylogenetic trees of amoA genes were based on the evolutionary distance (maximum likelihood algorithm with Jukes-Cantor model, 1000 bootstrap repetitions performed) using MEGA5 (Kumar et al., 2008).

\section{Results}

\subsection{Soil properties}

Results from one-way ANOVA have shown that most soil properties (except for nitrate-N, ammonium-N, and MBN) significantly decreased in the topsoil of B2 plots (Table 1). Soil pH was 0.5 units higher in the
B2 and B4 plots than that of B0 plots $(p<0.05)$. Soil total C and soil total $\mathrm{N}$ were significantly lower in the $\mathrm{B} 2$ plots compared with the other treatments, but the $\mathrm{C}: \mathrm{N}$ ratio showed no significant difference among the treatments. Mean DOC and DON both significantly decreased by ca. $30 \%$ in the B2 plots compared to the B0 plots from 77.4 to $46.8 \mathrm{mg} \mathrm{kg}^{-1}(p<0.05)$ and 18.0 to $12.6 \mathrm{mg} \mathrm{kg}^{-1}(p<0.01)$, respectively (Table 1). Mean MBC significantly decreased from $780 \mathrm{mg} \mathrm{kg}^{-1}$ in the B0 plots to $554 \mathrm{mg} \mathrm{kg}^{-1}$ in the B2 plots $(p<0.01)$, while there was no significant difference in MBN between the B0 and B2 plots. There were no significant differences in most soil properties measured between the $\mathrm{B} 0$ and $\mathrm{B} 4$ plots, except for soil $\mathrm{pH}$ which was lower in the $\mathrm{B} 0$ plots than in the B4 plots (Table 1).

\subsection{Abundances of soil 16S rRNA genes and amoA genes}

In 2005 samples, the abundance of soil bacterial 16S rRNA genes ranged from $1.90 \times 10^{8}$ to $5.47 \times 10^{8}$ copies $g^{-1}$ dry soil weight (dsw), 10-fold higher than that of archaeal 16S rRNA genes $(0.08 \times$ $10^{7}$ to $2.36 \times 10^{7}$ copies $\left.^{-1} \mathrm{dsw}\right)$ (Fig. 1a) $(p<0.01)$. The abundance of archaea was positively correlated with soil DOC and DON at both soil depths $(p<0.05)$ (Table 2$)$. However, the abundance of both soil bacteria $\left(2.48 \times 10^{7}\right.$ to $8.65 \times 10^{7}$ copies $\left.\mathrm{g}^{-1} \mathrm{dsw}\right)$ and archaea $\left(1.23 \times 10^{5}\right.$ to $2.27 \times 10^{6}$ copies $\left.^{-1} \mathrm{dsw}\right)$ was lower in 2010 samples. The abundance of AOA amoA genes $\left(2.48 \times 10^{6}\right.$ to $5.41 \times 10^{6}$ copies $^{-1}$ dsw) was over 10-fold higher than that of AOB $\left(0.76 \times 10^{5}\right.$ to $1.15 \times 10^{5}$ copies $\mathrm{g}^{-1} \mathrm{dsw}$ ) in 2005 samples (Fig. 1c). The abundance of AOB amoA gene was significantly higher in the $\mathrm{B} 2$ plots compared with the $\mathrm{B} 0$ plots $(p<0.05)$ in both 2005 and 2010 samples (Figs. 1c and 2c). However, copy numbers of archaeal $a m o A$ gene in the B0 treatment were over 7-fold higher than that of the B2 treatment of 2010 samples (Fig. 2c).

\subsection{Community composition and phylogenetic analysis of $A O B$ and $A O A$}

The diversity analyses of bacterial and archaeal amoA genes were only carried out in soil samples collected in 2005. Cloning and restriction fragment length polymorphism (RFLP) were performed to identify the community composition of AOB and AOA (Table 3). Clones displaying unique RFLP patterns were designated operational taxonomic units (OTUs) or genotypes, and representative clones were selected for sequencing. According to unique RFLP patterns, 21 OTUs of AOA and 6 OTUs of AOB were obtained. The rarefaction curve (Fig. 3 ) indicated that the clone libraries were sufficient to cover the amoA gene diversity. Phylogenetic affiliation analysis showed that amoA genes were classified as the Nitrosospira type for bacteria and the soil-related cluster for archaea (Figs. 4 and 5). Three bacterial amoA gene clusters (2, 9 and 11) were detected; cluster 2 is the dominant group (Table 3 ). Most genotypes of bacterial amoA genes were distributed in all treatments, except for cluster 11. In addition, an increase in cluster 2 was accompanied by a decrease in cluster 11 in the B2 plots (Table 3 ).

Table 1

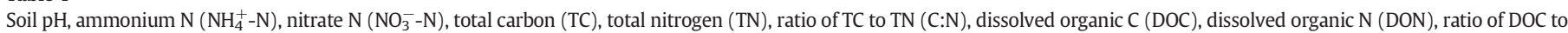
DON (DOC:DON), microbial biomass carbon (MBC) and microbial biomass nitrogen (MBN) under different prescribed burning regimes at the Peachester site, southeast Queensland.

\begin{tabular}{|c|c|c|c|c|c|c|c|c|c|c|c|}
\hline Treatment $^{\mathrm{a}}$ & $\mathrm{pH}$ & $\begin{array}{l}\mathrm{NO}_{3}^{-}-\mathrm{N} \\
\left(\mathrm{mg} \mathrm{kg}^{-1}\right)\end{array}$ & $\begin{array}{l}\mathrm{NH}_{4}^{+}-\mathrm{N} \\
\left(\mathrm{mg} \mathrm{kg}^{-1}\right)\end{array}$ & $\begin{array}{l}\text { TC } \\
(\%)\end{array}$ & $\begin{array}{l}\mathrm{TN} \\
(\%)\end{array}$ & $\mathrm{C}: \mathrm{N}$ & $\begin{array}{l}\text { DOC } \\
\left(\mathrm{mg} \mathrm{kg}^{-1}\right)\end{array}$ & $\begin{array}{l}\text { DON } \\
\left(\mathrm{mg} \mathrm{kg}^{-1}\right)\end{array}$ & DOC:DON & $\begin{array}{l}\text { MBC } \\
\left(\mathrm{mg} \mathrm{kg}^{-1}\right)\end{array}$ & $\begin{array}{l}\text { MBN } \\
\left(\mathrm{mg} \mathrm{kg}^{-1}\right)\end{array}$ \\
\hline \multicolumn{12}{|l|}{$0-10 \mathrm{~cm}$} \\
\hline B0 & $4.6 \pm 0.2 \mathbf{b}^{\mathrm{b}}$ & $6.5 \pm 2.7 \mathbf{a}$ & $1.9 \pm 2.4 a$ & $6.5 \pm 2.1 \mathbf{a}$ & $0.3 \pm 0.1 \mathbf{a}$ & $24.3 \pm 1.4 a$ & $77.4 \pm 8.1 \mathrm{a}$ & $18.0 \pm 3.0 \mathbf{a}$ & $4.4 \pm 0.6 \mathbf{a}$ & $780.1 \pm 146.3 \mathbf{a}$ & $73.7 \pm 16.4 \mathbf{a}$ \\
\hline B2 & $5.1 \pm 0.1 \mathrm{a}$ & $3.5 \pm 1.5 \mathbf{a}$ & $4.4 \pm 3.0 \mathbf{a}$ & $3.5 \pm 0.3 \mathbf{b}$ & $0.1 \pm 0.0 \mathbf{b}$ & $25.9 \pm 2.0 \mathbf{a}$ & $46.8 \pm 7.7 \mathbf{b}$ & $12.6 \pm 1.1 \mathbf{b}$ & $3.7 \pm 0.4 \mathbf{a}$ & $553.9 \pm 136.7 \mathbf{b}$ & $68.5 \pm 16.4 a$ \\
\hline B4 & $5.2 \pm 0.3 a$ & $4.2 \pm 3.6 \mathbf{a}$ & $3.6 \pm 4.3 \mathbf{a}$ & $6.6 \pm 0.5 a$ & $0.3 \pm 0.0 \mathbf{a}$ & $24.0 \pm 1.5 a$ & $74.4 \pm 20.9 \mathbf{a}$ & $19.5 \pm 2.8 \mathbf{a}$ & $3.8 \pm 0.6 \mathbf{a}$ & $880.8 \pm 43.0 \mathbf{a}$ & $89.1 \pm 4.3 \mathbf{a}$ \\
\hline \multicolumn{12}{|l|}{$10-20 \mathrm{~cm}$} \\
\hline B0 & $4.9 \pm 0.2 \mathbf{a}$ & $4.5 \pm 2.0 \mathbf{a}$ & $1.9 \pm 1.8 \mathbf{a}$ & $4.1 \pm 1.4 a$ & $0.2 \pm 0.1 \mathbf{a}$ & $23.6 \pm 0.6 \mathbf{a}$ & $40.9 \pm 5.3 \mathbf{a}$ & $16.5 \pm 3.0 \mathbf{a}$ & $2.5 \pm 0.6 \mathbf{a}$ & $419.6 \pm 128.8 \mathbf{a}$ & $44.4 \pm 6.3 \mathbf{a}$ \\
\hline B2 & $5.1 \pm 0.1 \mathrm{a}$ & $4.1 \pm 1.3 \mathbf{a}$ & $4.0 \pm 2.4 \mathbf{a}$ & $2.8 \pm 1.0 \mathbf{a}$ & $0.1 \pm 0.1 \mathbf{a}$ & $24.4 \pm 2.4 \mathbf{a}$ & $33.4 \pm 7.5 \mathbf{a}$ & $11.5 \pm 1.4 \mathbf{b}$ & $2.9 \pm 0.5 \mathbf{a}$ & $430.5 \pm 88.3 \mathbf{a}$ & $50.8 \pm 8.7 \mathbf{a}$ \\
\hline B4 & $5.2 \pm 0.4 a$ & $3.2 \pm 2.4 \mathbf{a}$ & $3.5 \pm 2.8 \mathbf{a}$ & $4.0 \pm 0.4 a$ & $0.2 \pm 0.0 \mathbf{a}$ & $22.8 \pm 1.6 \mathbf{a}$ & $40.5 \pm 6.4 a$ & $17.8 \pm 2.6 \mathbf{a}$ & $2.3 \pm 0.1 \mathbf{a}$ & $552.2 \pm 83.7 \mathbf{a}$ & $52.6 \pm 9.6 \mathbf{a}$ \\
\hline
\end{tabular}

\footnotetext{
a B0: Never burnt; B2: biennially burnt; B4: quadrennially burnt.
}

b Difference is significant at the 0.05 level (LSD). 

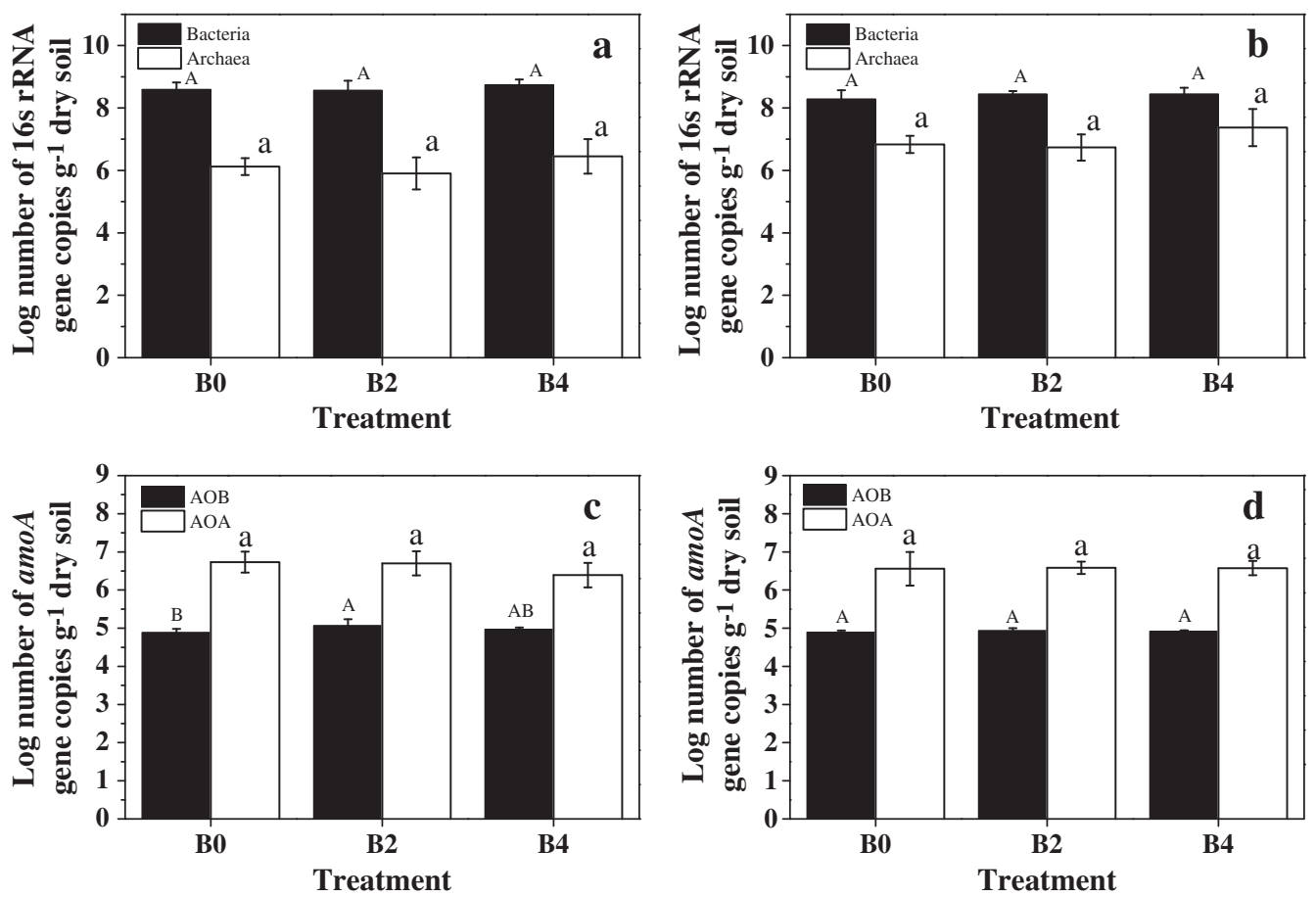

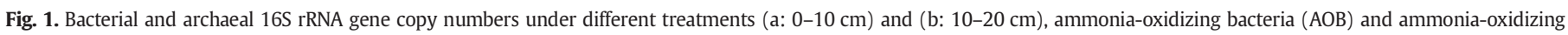
archaea (AOA) amoA gene copy numbers under different treatments (c: 0-10 cm) and (d: 10-20 cm) in 2005. B0, never burnt; B2, biennially burnt; B4, quadrennially burnt.

Twenty-one thaumarchaeal amoA genotypes fell into two clusters, designated as soil clusters 2 and 5 . According to the reference sequences (JN227489, EF207225, FR773159), 14 thaumarchaeal amoA genotypes revealed a pH-associated distribution from acido-neutral $(5 \leq \mathrm{pH}<7)$ to acidic soils $(\mathrm{pH}<5)$. However, most thaumarchaeal amoA genes associated with Candidatus Nitrososphaera (FR773159) were found in the control plots. RFLP analysis results showed that the dominant soil cluster 2 (group 1.1b) decreased, while soil cluster 5 (group 1.1a) increased in the burnt plots (Table 3 ).

\subsection{Communities of $A O B$ and $A O A$ in response to environmental factors}

Canonical correspondence analysis (CCA) was performed to investigate the environmental factors influencing the community composition, evaluating the relationship between the soil parameters (Table 1) and the dominant amoA gene RFLP genotypes (Table 3). According to the AIC, five different factors were selected to interpret the distribution of bacterial amoA genes and archaeal amoA genes in both topsoil and subsoil. Two axes of the CCA explained 39.3\% of the total variance in the bacterial amoA genotype composition and $98.1 \%$ of the cumulative variance of the genotype-environment relationship in topsoil (Fig. 6a). Only soil DOC significantly influenced the distribution of $\mathrm{AOB}$ amoA genotypes $(F=4.28, p=0.01,1000$ permutations). For subsoil, two axes of the CCA explained $49.9 \%$ of the total variance in the bacterial amoA genotype composition and $79.7 \%$ of the cumulative variance of the genotype-environment relationship (Fig. 6b). Soil pH significantly affected the bacterial amoA gene composition among the treatments $(F=3.47, p=0.01,1000$ permutations), followed by TC ( $F=2.48, p=0.07,1000$ permutations). On the other hand, more than half of the total variance (53.7\%) and the majority of the cumulative variance $(78.7 \%)$ of the archaeal amoA gene composition versus environmental variables were explained by the first two axes of the CCA in topsoil (Fig. 6c). The CCA results indicated that nitrate-N $(p<0.01), \operatorname{MBN}(p=0.03)$ and DOC $(p=0.06)$

Table 2

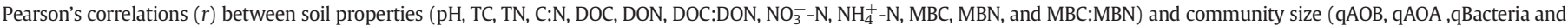
qArchaea) measured at each individual sampling point $(n=12)$.

\begin{tabular}{|c|c|c|c|c|c|c|c|c|}
\hline & \multicolumn{4}{|l|}{$0-10 \mathrm{~cm}$} & \multicolumn{4}{|l|}{$10-20 \mathrm{~cm}$} \\
\hline & qBacteria & qArchaea & qAOB & $\mathrm{qAOA}$ & qBacteria & qArchaea & qAOB & $\mathrm{qAOA}$ \\
\hline $\mathrm{pH}$ & 0.32 & 0.45 & 0.54 & -0.56 & 0.48 & $0.62^{*}$ & 0.17 & 0.19 \\
\hline TC & 0.33 & 0.50 & -0.20 & -0.14 & 0.14 & 0.36 & -0.03 & 0.21 \\
\hline TN & 0.31 & 0.43 & -0.17 & -0.11 & 0.11 & 0.30 & -0.10 & 0.21 \\
\hline $\mathrm{C}: \mathrm{N}$ & 0.50 & 0.14 & 0.40 & $0.60^{*}$ & 0.03 & -0.13 & 0.57 & 0.04 \\
\hline $\mathrm{DOC}$ & 0.36 & $0.67^{*}$ & -0.47 & -0.43 & 0.18 & $0.65^{*}$ & 0.35 & -0.15 \\
\hline DON & 0.45 & $0.73^{* *}$ & -0.25 & -0.37 & 0.19 & $0.70^{* *}$ & -0.02 & 0.20 \\
\hline DOC:DON & 0.02 & 0.15 & $-0.63^{*}$ & -0.18 & -0.02 & -0.22 & 0.34 & -0.32 \\
\hline $\mathrm{NO}_{3}^{-}-\mathrm{N}$ & -0.33 & -0.56 & -0.27 & 0.48 & -0.47 & $-0.68^{*}$ & -0.55 & 0.03 \\
\hline $\mathrm{NH}_{4}^{+}-\mathrm{N}$ & 0.49 & $0.69^{*}$ & 0.31 & -0.34 & 0.17 & 0.41 & 0.22 & 0.10 \\
\hline MBC & -0.14 & 0.27 & -0.36 & $-0.59^{*}$ & 0.10 & 0.33 & -0.07 & -0.01 \\
\hline MBN & -0.32 & 0.14 & -0.14 & $-0.81^{* *}$ & -0.06 & -0.02 & 0.11 & -0.14 \\
\hline MBC:MBN & 0.19 & 0.21 & -0.34 & 0.17 & 0.18 & 0.49 & 0.03 & 0.12 \\
\hline
\end{tabular}

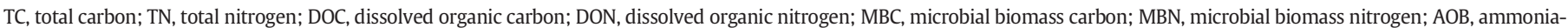
oxidizing bacteria; AOA, ammonia-oxidizing archaea.

Values in bold are statistically significant. ${ }^{* *} p<0.01 ;{ }^{*} p<0.05$ 

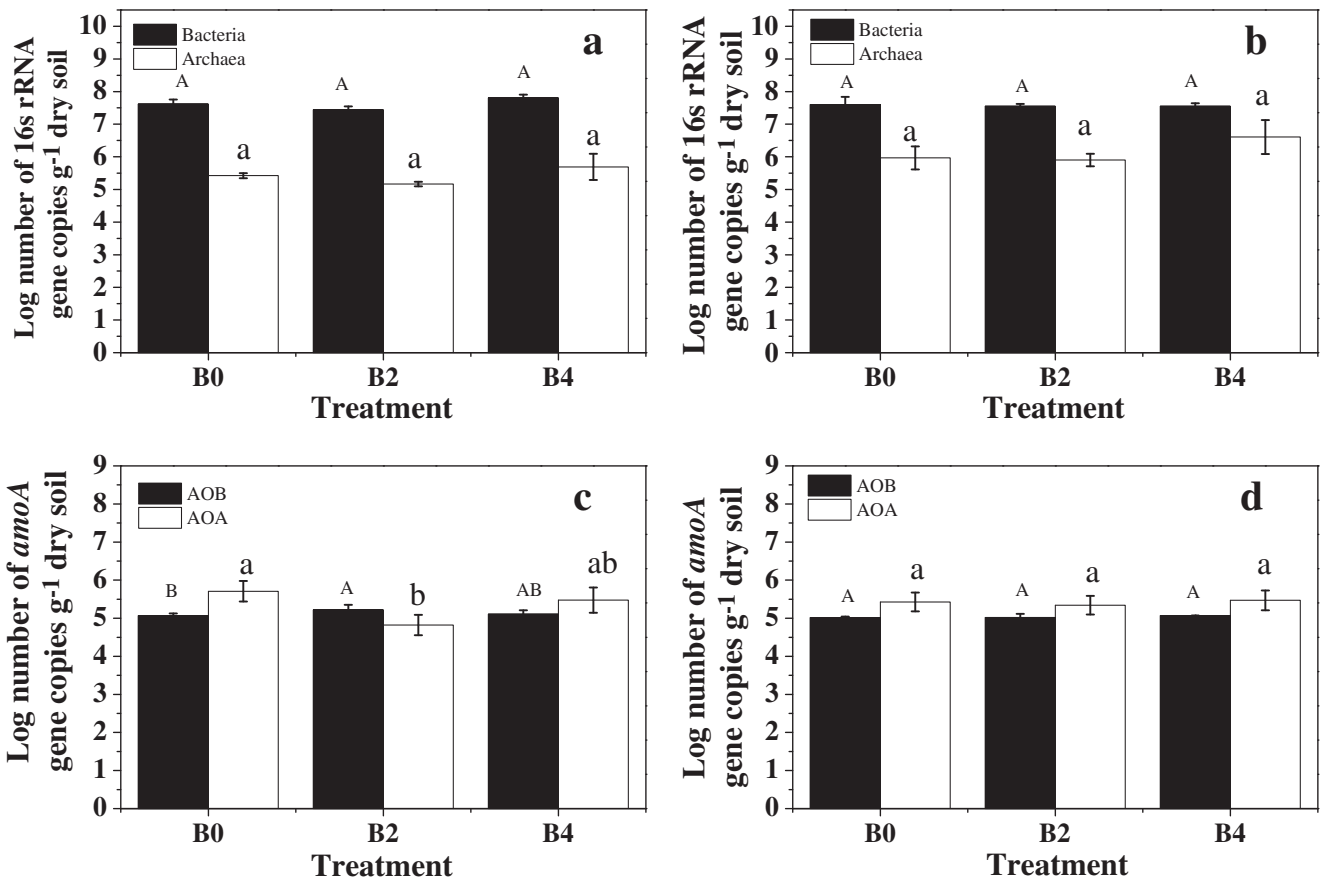

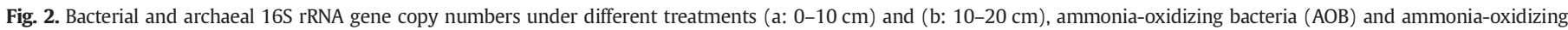
archaea (AOA) amoA gene copy numbers under different burning treatments (c: 0-10 cm) and (d: 10-20 cm) in 2010. B0, never burnt; B2, biennially burnt; B4, quadrennially burnt.

significantly affected the distribution of AOA amoA genotypes. Only $31.5 \%$ of the total variance and $58.9 \%$ of the cumulative variance of the archaeal genotype-environmental relationship were explained by the first two axes of the CCA in subsoil (Fig. 6d). Soil TC $(p=0.09)$ significantly affected the distribution of AOA amoA genes (Fig. 6d).

\subsection{Molecular variance of amoA gene sequences}

The haplotypic form of RFLP data was used to evaluate the molecular variance of amoA gene among the different treatments. Hierarchical genetic structures of archaeal $a m o A$ genes were detected among the populations within the treatment $\left(0-10 \mathrm{~cm}: F_{\mathrm{SC}}=0.37\right.$ and $10-20 \mathrm{~cm}$ : $\left.F_{\mathrm{SC}}=0.07\right)$ and within populations across all samples $\left(0-10 \mathrm{~cm}: F_{\mathrm{ST}}=\right.$ 0.36 and $\left.10-20 \mathrm{~cm}: F_{\mathrm{SC}}=0.11\right)$. Replicate variation of each treatment contributed $38.18 \%(0-10 \mathrm{~cm})$ and $12.75 \%(10-20 \mathrm{~cm})$ to the total genetic variation, while variation in the populations of all samples accounted for ca. $64.04 \%(0-10 \mathrm{~cm})$ and $85.16 \%(10-20 \mathrm{~cm})$ (Table 4). AMOVA results indicated that the main variation of $A O B$ amoA gene came from the populations among all samples $(0-10 \mathrm{~cm}: 88.75 \%$ and $10-20 \mathrm{~cm}$ : 96.55\%). Despite a small contribution of the variation in populations among the treatments to total genetic variation
(0-10 cm: $2.09 \%$ and $10-20 \mathrm{~cm}: 1.98 \%)$, there were significant differences in bacterial amoA genes among the treatments $(0-10 \mathrm{~cm}$ : p 0.05; 10-20 cm: $p<0.10$ ) (Table 4).

\section{Discussion}

Lower pH observed in the prescribed burning plots (B2 and B4 plots) compared with the control plot (BO) (Table 1) was due to the increased inputs of ashes containing oxides, hydroxides and carbonates of alkaline elements (K, Na, Ca and Mg) (Khanna et al., 1994; Ulery et al., 1993). Soil TC, TN, DOC, DON, and MBN were lower in the more frequent burning plots (B2 plots) compared with the B0 and B4 plots. This may be associated with reduced inputs of organic matter and increased erosion loss of organic matter (e.g. Knicker, 2007; Wardle et al., 2008). However, there were no significant differences in most soil properties between the $\mathrm{B} 0$ and $\mathrm{B} 4$ plots, indicating that the ecosystem processes could recover in less frequent burning treatments (B4 plots). In addition, there were no significant differences in soil properties at the $10-20 \mathrm{~cm}$ among the three treatments, indicating that the effect of fires was confined to the topsoil.

Table 3

Fragment patterns of $a m o A$ genes and distribution of sequence types affiliated with amoA clusters in the clone libraries (\%).

\begin{tabular}{|c|c|c|c|c|c|c|c|c|c|}
\hline \multirow[t]{2}{*}{ Treatment } & \multicolumn{4}{|l|}{ AOA } & \multicolumn{5}{|l|}{ AOB } \\
\hline & Pattern number ${ }^{\mathrm{a}}$ & Soil cluster $2^{\mathrm{b}}$ & Soil cluster 5 & Ratio of soil cluster $2 / 5$ & Pattern number & Cluster 2 & Cluster 9 & Cluster 11 & Ratio of cluster $2 / 11$ \\
\hline \multicolumn{10}{|l|}{$0-10 \mathrm{~cm}$} \\
\hline B0 & 9 & $99.6 \%$ & $0.4 \%$ & 249.0 & 5 & $75.4 \%$ & $0.8 \%$ & $23.8 \%$ & 3.2 \\
\hline B2 & 4 & $78.9 \%$ & $21.1 \%$ & 3.7 & 4 & $89.9 \%$ & $1.5 \%$ & $8.6 \%$ & 10.5 \\
\hline B4 & 8 & $87.3 \%$ & $12.7 \%$ & 6.9 & 4 & $71.5 \%$ & $0.5 \%$ & $28.0 \%$ & 2.6 \\
\hline \multicolumn{10}{|l|}{$10-20 \mathrm{~cm}$} \\
\hline B0 & 7 & $90.7 \%$ & $9.3 \%$ & 9.8 & 5 & $70.1 \%$ & $0.4 \%$ & $29.5 \%$ & 2.4 \\
\hline B2 & 8 & $80.4 \%$ & $19.6 \%$ & 4.1 & 5 & $83.2 \%$ & $0.9 \%$ & $15.9 \%$ & 5.2 \\
\hline B4 & 8 & $74.7 \%$ & $25.3 \%$ & 3.0 & 5 & $78.7 \%$ & $1.0 \%$ & $20.3 \%$ & 3.9 \\
\hline
\end{tabular}

a Pattern numbers are numbers of molecular fragments following digestion with HaelII and Mbol.

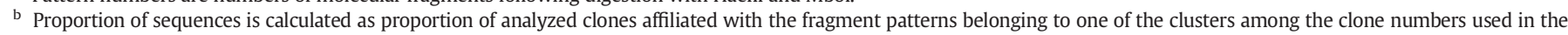
digestion analysis in one clone library. 

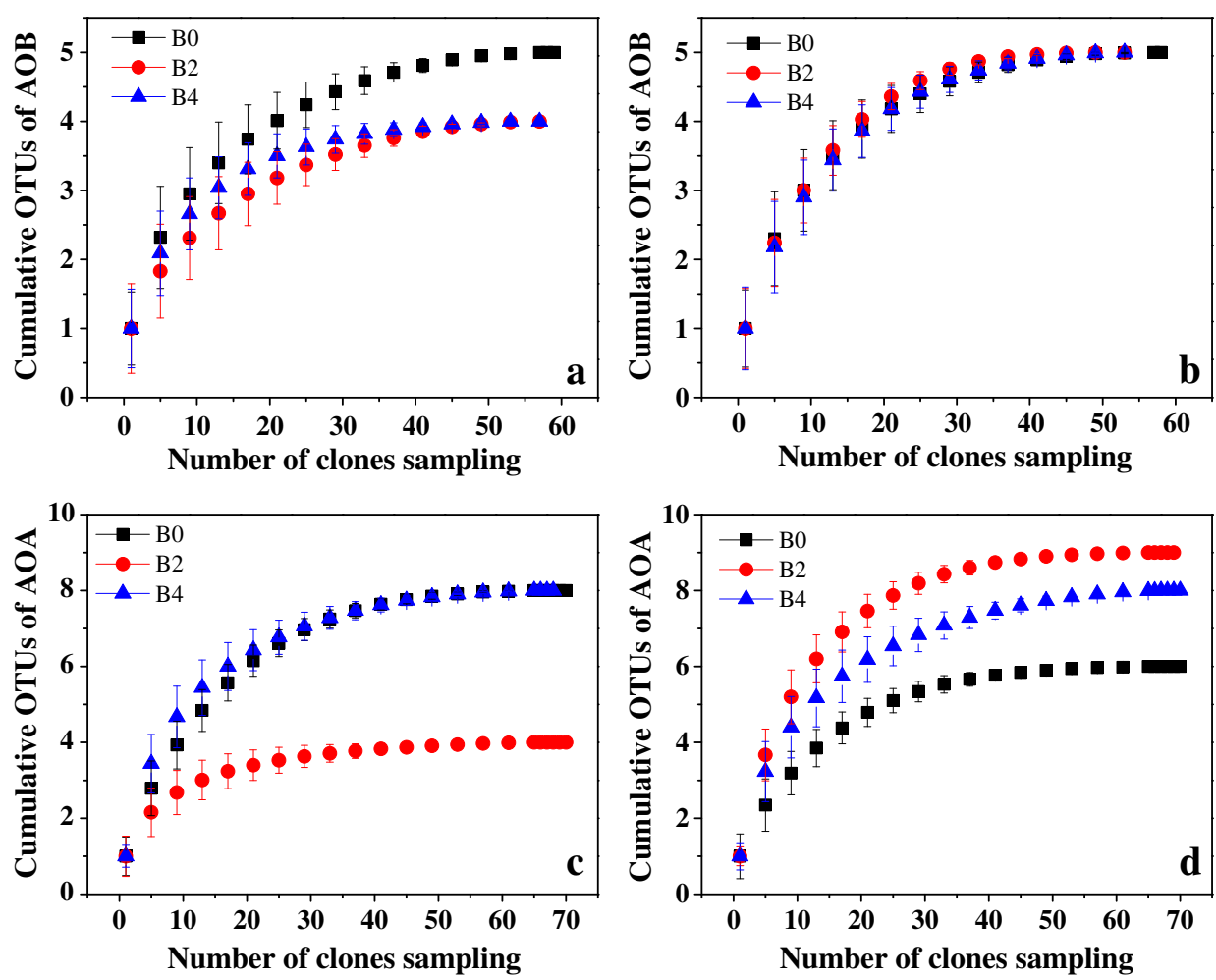

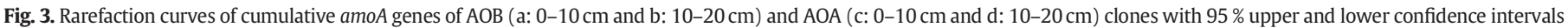
(error bars) for three prescribed burning treatments (never burnt, B0; biennially burnt, B2; quadrennially burnt, B4) at the Peachester site.

\subsection{Effects of long-term prescribed burning on the abundance of $16 \mathrm{~S} r R N A$ and amoA genes}

It has been reported that fire stimulated the growth of bacteria due to nutrient input via ash deposition and simultaneously reduced the growth of fungal populations (Bissett and Parkinson, 1980; Pietikäinen and Fritze, 1995). Vázquez et al. (1993) had found a short-term stimulation of fire on the microbial population size. However, this beneficial effect of burning disappeared after 1 year. They supposed that in the long term gradual leaching of ash minerals to lower soil layers and a loss of structure due to burning made the microbial population sizes return to normal (Vázquez et al., 1993). In our study, insignificant effects of fire on the abundance of bacteria and archaea may be partly explained by the relatively constant ratio of soil C:N and
DOC:DON among the treatments in both soil depths. It has been suggested that soil nutrient stoichiometry controlled the metabolism and growth of microorganisms (Elser and Hamilton, 2007; Sterner and Elser, 2002). In general, Kandosols have a coarse-texture with low fertility and poor water holding capacity. Plants or other microbes rapidly seized the brief nutrient pulses and niche vacancy following fire. In addition, the positive correlation between archaeal abundance and soil DOC or DON indicated a more effective usage of available C or $\mathrm{N}$ sources than bacteria at this site, which favoured their adaptation to the environmental stresses such as fire.

On the contrary, a study in the pine forest in Japan found that the abundance of culturable microorganisms was the lowest in the soil samples collected immediately after fire, followed by the samples collected 2 years after fire and the unburned samples (Mabuhay et al.,

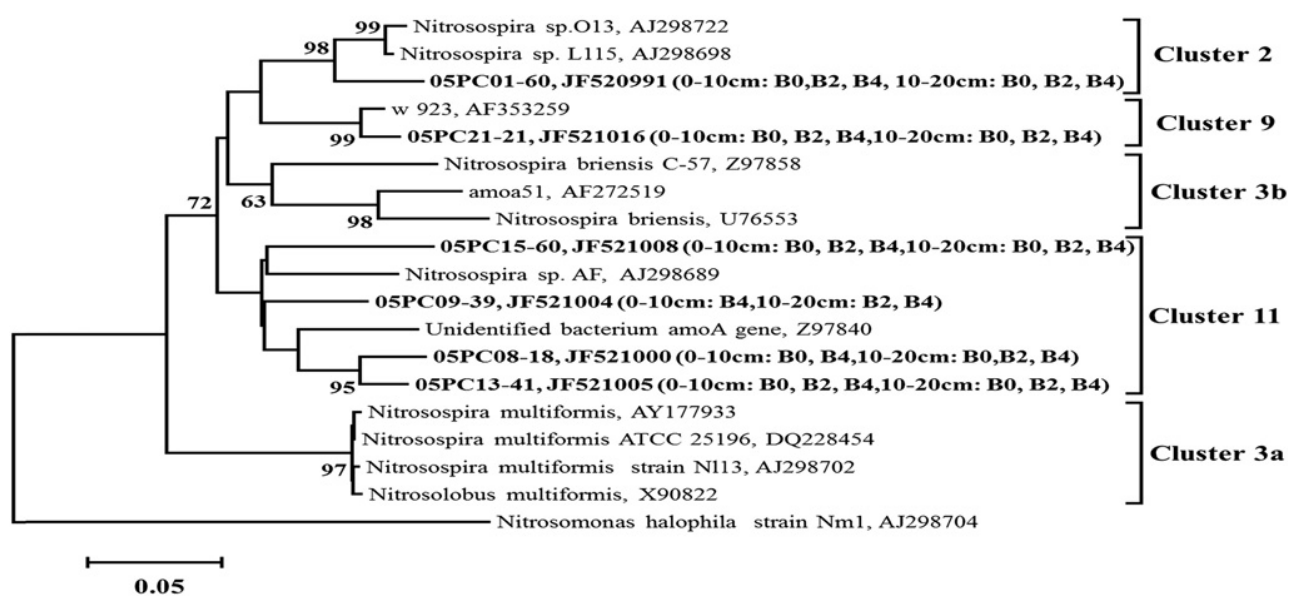

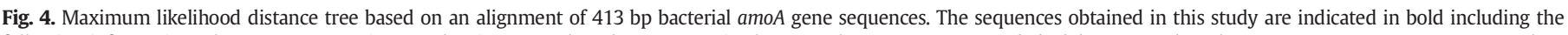

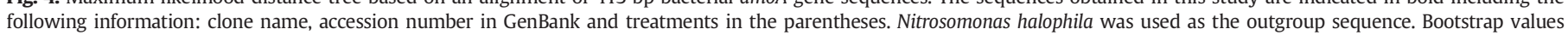
(>60\%) are indicated at branch points. The scale bar represents $5 \%$ sequence divergence. 


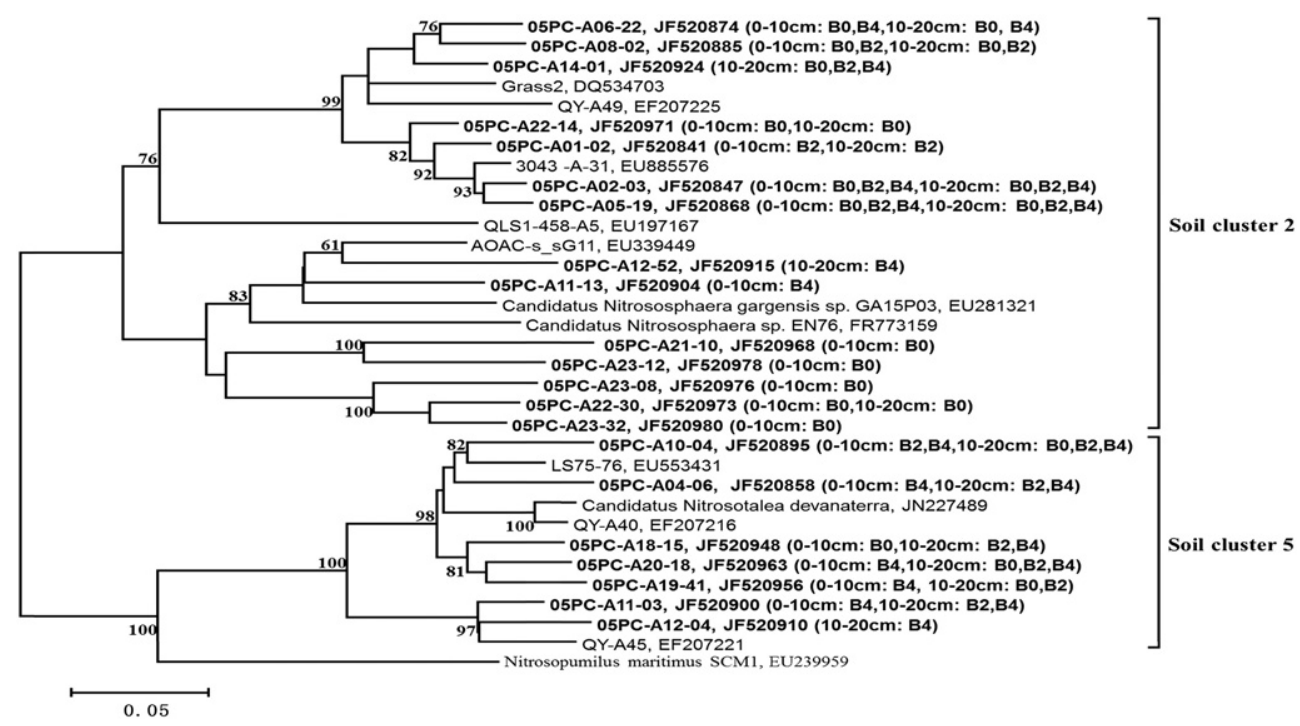

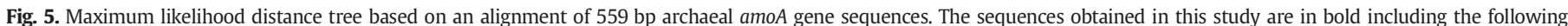

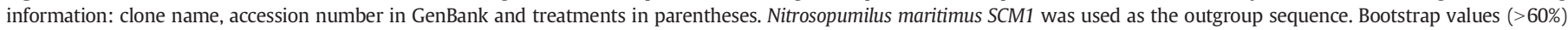
are indicated at branch points. The bar shows a relative distance of 0.05 .

2003). Moreover, Mabuhay et al. (2004) investigated the microbial abundance of one unburned site and another 5 different post-fire sites (2 months and 3, 6, 9 and 25 years) and found that the highest abundances of Gram-positive, Gram-negative bacteria and actinomycetes in the control site.

Our results showed a positive impact of the fire on the abundance of AOB in the topsoil of the B2 plots in comparison with the B0 plots, possibly due to the increase in soil $\mathrm{pH}$. Similar results were found in a ponderosa pine forest, where Ball et al. (2010) speculated that the growth of $\mathrm{AOB}$ was stimulated by the $\mathrm{pH}$ improvement and adsorption of soil nitrification inhibitors by the fire-generated charcoal. However, no significant changes in the abundance of $\mathrm{AOB}$ between the B4 plots and the $\mathrm{BO}$ plots indicated that soil $\mathrm{pH}$ was not the only dominant environmental factor on the growth of AOB in this study. It has been suggested that soil heating favors the growth of autotrophic nitrifiers in competition with heterotrophs for ammonium and additional nutrients from ash (Bauhus et al., 1993). However, the effects of fire on AOB appeared to be weak in a California annual grassland (Docherty et al., 2011), and negative in a mixed conifer forest (Yeager et al., 2005). These could be attributed to the competition between
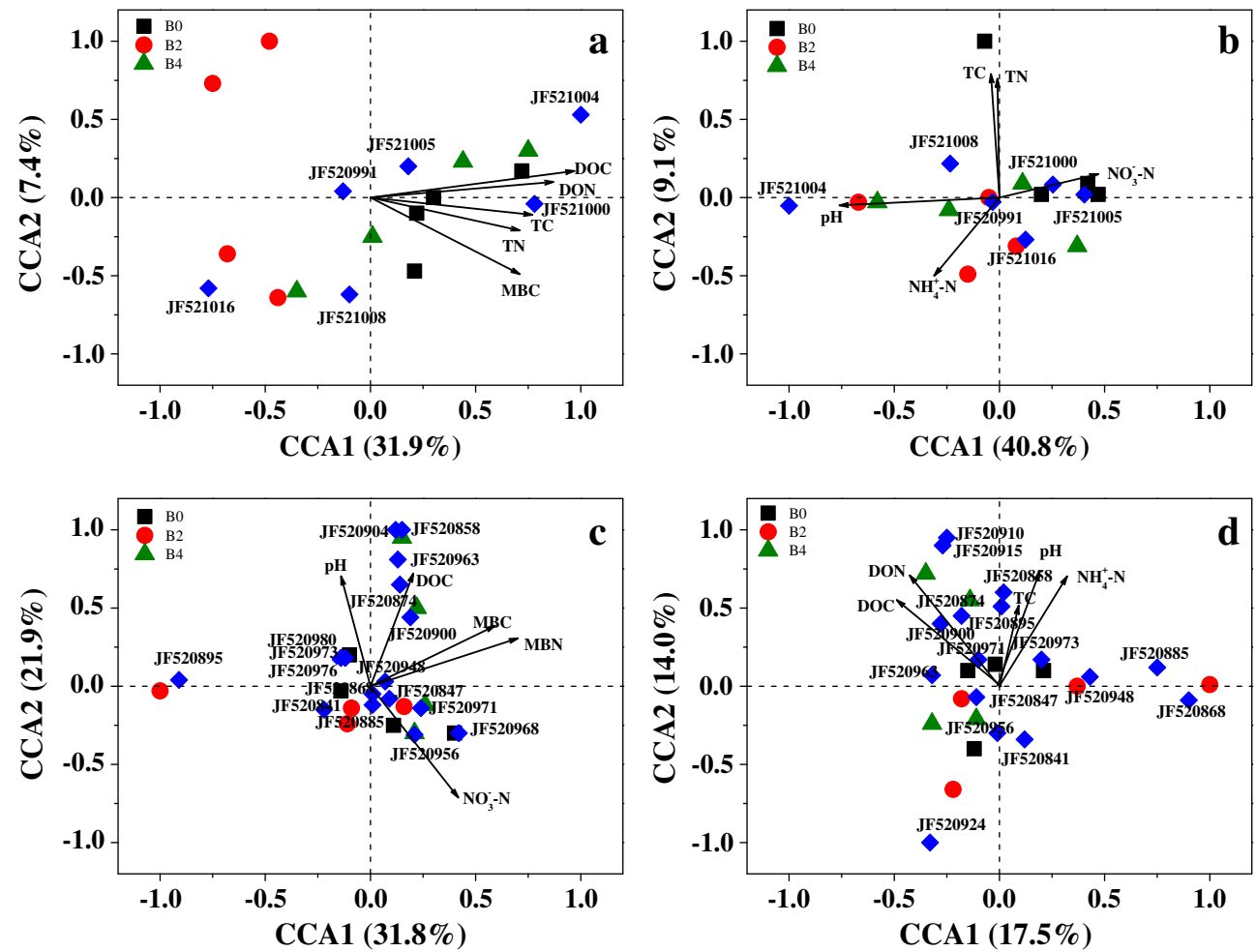

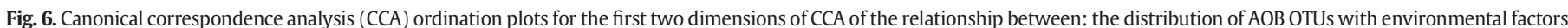

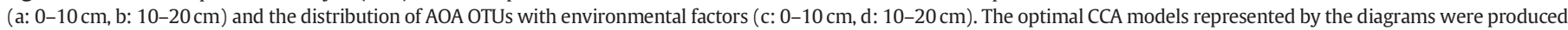

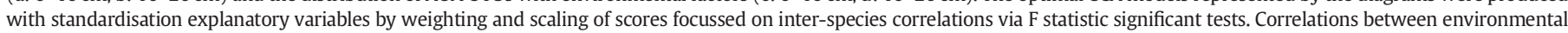
variables and CCA axes are represented by the length and angle of lines (environmental factor vectors). 
Table 4

Arlequin AMOVA analyses of $a m o A$ gene sequences of Peachester forest soils by RFLP genotype frequencies.

\begin{tabular}{|c|c|c|c|c|c|}
\hline \multicolumn{6}{|c|}{$0-10 \mathrm{~cm}$} \\
\hline \multirow[t]{4}{*}{ AOA } & Source of variation & Variance components & $\%$ of variation & F-statistics & $p$ \\
\hline & Among treatments & $-0.04 \mathrm{Va}$ & -2.22 & $F_{\mathrm{CT}}=-0.02$ & $0.65 \pm 0.01$ \\
\hline & Replicates/treatment & $0.66 \mathrm{Vb}$ & 38.18 & $F_{\mathrm{SC}}=0.37$ & $0.00 \pm 0.00$ \\
\hline & Among all samples & $1.10 \mathrm{Vc}$ & 64.04 & $F_{\mathrm{ST}}=0.36$ & $0.00 \pm 0.00$ \\
\hline \multirow[t]{4}{*}{$\mathrm{AOB}$} & Source of variation & Variance components & $\%$ of variation & F-statistics & $p$ \\
\hline & Among treatments & $0.12 \mathrm{Va}$ & 4.79 & $F_{\mathrm{CT}}=0.05$ & $0.04 \pm 0.00$ \\
\hline & Replicates/treatment & $0.16 \mathrm{Vb}$ & 6.46 & $F_{\mathrm{SC}}=0.07$ & $0.00 \pm 0.00$ \\
\hline & Among all samples & $2.24 \mathrm{Vc}$ & 88.75 & $F_{\mathrm{ST}}=0.11$ & $0.00 \pm 0.00$ \\
\hline \multicolumn{6}{|c|}{$10-20 \mathrm{~cm}$} \\
\hline \multirow[t]{4}{*}{$\mathrm{AOA}$} & Source of variation & Variance components & $\%$ of variation & F-statistics & $p$ \\
\hline & Among treatments & $0.05 \mathrm{Va}$ & 2.09 & $F_{\mathrm{CT}}=0.02$ & $0.15 \pm 0.01$ \\
\hline & Replicates/treatment & $0.30 \mathrm{Vb}$ & 12.75 & $F_{\mathrm{SC}}=0.13$ & $0.00 \pm 0.00$ \\
\hline & Among all samples & $2.02 \mathrm{Vc}$ & 85.16 & $F_{\mathrm{ST}}=0.15$ & $0.00 \pm 0.00$ \\
\hline \multirow[t]{4}{*}{$\mathrm{AOB}$} & Source of variation & Variance components & $\%$ of variation & F-statistics & $p$ \\
\hline & Among treatments & $0.05 \mathrm{Va}$ & 1.98 & $F_{\mathrm{CT}}=0.02$ & $0.07 \pm 0.01$ \\
\hline & Replicates/treatment & $0.04 \mathrm{Vb}$ & 1.47 & $F_{\mathrm{SC}}=0.01$ & $0.04 \pm 0.01$ \\
\hline & Among all samples & $2.41 \mathrm{Vc}$ & 96.55 & $F_{\mathrm{ST}}=0.03$ & $0.00 \pm 0.00$ \\
\hline
\end{tabular}

plants and plant-associated arbuscular mycorrhizal fungi (AMF) with AOB for nutrients inputs by the ash, and a slow recovery rate of microbial biomass caused by low soil moisture content (Docherty et al., 2011; Yeager et al., 2005). A decreasing abundance of AOA in 2010 samples and a negative relationship between the abundance of $\mathrm{AOA}$ and soil $\mathrm{pH}$ in 2005 samples indicated an impact of fire on the growth of AOA. In a recent study, O'Sullivan et al. (2012) also found the abundance of $\mathrm{AOA}$ was reversely interrelated to soil $\mathrm{pH}$ in two agricultural systems with $360 \mathrm{~kg}$ and $65 \mathrm{kgN}$ per ha per year in Australia.

\subsection{Effects of long-term prescribed burning on $A O B$ and $A O A$ community composition}

The fire greatly affected the ratio of clusters $2-11$ of the AOB community structure at both soil depths, which increased from 2.4-3.9 in the B0 and B4 plots to 5.2-10.5 in the B2 plots (Table 3). The shift in AOB community structures might be due to burningassociated increases in soil $\mathrm{pH}$ and ammonium- $\mathrm{N}$ level. The similar results have been reported in a mixed conifer forest ecosystem with dominant soil cluster 3a in burned soils (Yeager et al., 2005) and a ponderosa pine forest with dominant soil clusters 3 and 4 in recentfire soils (Ball et al., 2010). However, the cluster 3a sequence of AOB was not detected in this study. The alteration of $A O B$ populations in the fire-impacted plots was confirmed by the results of phylogenetic tree analysis and AMOVA. For example, one genotype (JF5210004) of cluster 11 was only detected in the burned plots and the molecular variance among the treatments was significant in both soil depths.

Phylogenetic analyses of bacterial amo $A$ genes showed that Nitrosospira cluster 2 was predominant among the treatments (Fig. 4), in agreement with previous findings that Nitrosospira cluster 2 sequences were dominant in acidic forest soils (Nugroho et al., 2005). Nitrosospira cluster 11 possessed nearly one-quarter ratio in the clone library and four amoA genotypes indicated cluster 11 as an important contributor to nitrification at our study site (Fig. 4, Table 4). In addition, CCA results indicated that soil DOC was positively correlated with the dominant genotypes of AOB (JF520991, JF521005 and JF521000) in the topsoil (Fig. 6a). Previous studies at the same study area have demonstrated that fungal community composition in the B2 plots was significantly different from that in $\mathrm{B} 0$ or $\mathrm{B} 4$ plots due to the change in soil C and $\mathrm{N}$ (e.g. Bastias et al., 2006a). Meanwhile, soil pH and TC were found to have significant effects on the AOB community composition in the topsoil.
The investigation of wildfire or prescribed burning on the soil ammonium- $\mathrm{N}$ and nitrate- $\mathrm{N}$ had demonstrated that both inorganic $\mathrm{N}$ increased immediately after the fire, but these improvements were dissipated in 1 year or more post-fire (Covington et al., 1991; Covington and Sackett, 1992; Smith et al., 2008). The CCA results showed a positive correlation between soil nitrate-N and dominant AOA genotypes (JF520847, JF520868 and JF520885) (Fig. 6c), which were only detected in the soil cluster 2 . Interestingly, the impact of the fire on the AOA community composition not only manifested in the decrease of the ratio of soil clusters $2-5$ under B2 or B4 plots but also different genotype numbers of AOA among the treatments (Table 3).For example, there were 10 genotypes of soil cluster 2 in the topsoil of B0 plots but 4 in the B2 or B4 plots. In particular, six (JF520971, JF520968, JF520978, JF520976, JF520973 and JF520980), one (JF520841) and three (JF520915, JF520904 and JF520910) unique genotypes were detected in the B0, B2 and B4 plots, respectively (Fig. 5). In addition, most genotypes of soil cluster 5 were detected in the topsoil of B4 plots except for JF520895 and JF520948 (Fig. 5). Therefore, the shift of AOA genotypes between the control (BO) and the B4 plots indicated that the 4 year interval fire could affect the AOA community composition.

\section{Conclusions}

In summary, results from this study have demonstrated that prescribed fires did not change the abundance of bacteria and archaea, while more frequent burning (B2 plots) significantly increased the abundance of bacterial amoA gene, but tended to decrease archaeal amoA genes. This may imply a more important role of $\mathrm{AOB}$ in nitrification in this acidic soil after the long-term prescribed burning. Fire has also modified the composition of AOA and AOB communities, which could be explained by changes in the key soil parameters (e.g. DOC, MBN, pH and TC) due to the fires. Further studies are needed to confirm the relationship between the nitrification rate and the AOA and $\mathrm{AOB}$ abundances and community structures at the study site and to explore the implication of shifts in $\mathrm{AOA}$ and $\mathrm{AOB}$ communities due to the fires for $\mathrm{N}$ management in forest ecosystems.

\section{Conflict of interest}

The authors have declared that there were no conflicts of interests involved in this work. 


\section{Acknowledgements}

We would like to thank the Department of Agriculture, Forestry and Fishery, Queensland, for the access to the Peachester State Forest experimental site. This project was supported by ARC Discovery Project (DP0664154 and DP1092470) and Future Fellowship (FT0990547).

\section{References}

Ball PN, MacKenzie MD, DeLuca TH, Holben WE. Wildfire and charcoal enhance nitrification and ammonium-oxidizing bacterial abundance in dry montane forest soils. J Environ Qual 2010;39:1243-53.

Bastias BA, Huang ZQ Blumfield T, Xu Z, Cairney JWG. Influence of repeated prescribed burning on the soil fungal community in an eastern Australian wet sclerophyll forest. New Phytol 2006a;38:3492-501.

Bastias BA, Xu Z, Cairney JWG. Influence of long-term repeated prescribed burning on mycelial communities of ectomycorrhizal fungi. New Phytol 2006b;172:149-58.

Bauhus J, Khanna PK, Raison RJ. The effect of fire on carbon and nitrogen mineralization and nitrification in an Australian forest soil. Aust J Soil Res 1993:31:621-39.

Bissett J, Parkinson D. Long-term effects of fire on the composition and activity of the soil microflora of a subalpine, coniferous forest. Can J Bot 1980;58:1704-21

Bond WJ, Van Wilgen BW. Fire and plants, vol. 14. London: UK: Chapman \& Hall; 1996.

Bradstock RA. Flammable Australia: the fire regimes and biodiversity of a continent. Cambridge: UK: Cambridge University Press.; 2002.

Caffrey JM, Bano N, Kalanetra K, Hollibaugh JT. Ammonia oxidation and ammoniaoxidizing bacteria and archaea from estuaries with differing histories of hypoxia. ISME J 2007; 1:660-2.

Campbell CD, Cameron CM, Bastias BA, Chen C, Cairney JWG. Long term repeated burning in a wet sclerophyll forest reduces fungal and bacterial biomass and responses to carbon substrates. Soil Biol Biochem 2008;40:2246-52.

Cary G. Importance of a changing climate for fire regimes in Australia. Cambridge University Press; 200226-46.

Certini G. Effects of fire on properties of forest soils: a review. Oecologia 2005;143:1-10.

Chen CR, Xu ZH, Zhang SL, Keay P. Soluble organic nitrogen pools in forest soils of subtropical Australia. Plant Soil 2005;277:285-97.

Colwell RK. EstimateS: statistical estimation of species richness and shared species from samples. Version 8.2. User's Guide and application; 2009.

Covington WW, Debano LF, Huntsberger TG. Soil nitrogen changes associated with slash pile burning in pinyon-juniper woodlands. For Sci 1991;37:347-55.

Covington WW, Sackett SS. Soil mineral nitrogen changes following prescribed burning in ponderosa pine. For Ecol Manag 1992;54:175-91.

De Vet W, Dinkla IJT, Muyzer G, Rietveld LC, Van Loosdrecht MCM. Molecular characterization of microbial populations in groundwater sources and sand filters for drinking water production. Water Res 2009;43:182-94.

Di HJ, Cameron KC, Shen JP, Winefield CS, O'Callaghan M, Bowatte S, et al. Nitrification driven by bacteria and not archaea in nitrogen-rich grassland soils. Nat Geosci 2009:2:621-4.

Docherty KM, Balser TC, Bohannan BJM, Gutknecht JLM. Soil microbial responses to fire and interacting global change factors in a California annual grassland. Biogeochemistry 2011;109:1-21.

Elser JJ, Hamilton A. Stoichiometry and the new biology: the future is now. PLoS Biol 2007; 5:e181.

Excoffier L, Lischer HEL. Arlequin suite ver 3.5: a new series of programs to perform population genetics analyses under Linux and Windows. Mol Ecol Resour 2010;10: 564-7.

Francis CA, Roberts KJ, Beman JM, Santoro AE, Oakley BB. Ubiquity and diversity of ammonia-oxidizing archaea in water columns and sediments of the ocean. Proc Natl Acad Sci U S A 2005;102:14683-8.

Fuhrman JA. Microbial community structure and its functional implications. Nature 2009;459:193-9.

Guinto DF, Xu ZH, House APN, Saffigna PG. Soil chemical properties and forest floor nutrients under repeated prescribed burning in eucalypt forests of south-east Queensland, Australia. New Zeal J For Sci 2001;31:170-87.

He JZ, Shen JP, Zhang LM, Zhu YG, Zheng YM, Xu MG, et al. Quantitative analyses of the abundance and composition of ammonia-oxidizing bacteria and ammoniaoxidizing archaea of a Chinese upland red soil under long-term fertilization practices. Environ Microbiol 2007;9:2364-74.

Herrmann M, Saunders AM, Schramm A. Archaea dominate the ammonia-oxidizing community in the rhizosphere of the freshwater macrophyte Littorella uniflora. Appl Environ Microbiol 2008;74:3279-83.
Isbell RF. The Australian soil classification. vol. 4CSIRO Publishing; 2002.

Jenkinson DS. Determination of microbial biomass carbon and nitrogen in soil. In: Wilson JR, editor. Advances in Nitrogen Cycling in Agricultural Ecosystem. Wallingford, UK: CAB International; 1988. p. 368-85.

Könneke M, Bernhard AE, José R, Walker CB, Waterbury JB, Stahl DA. Isolation of an autotrophic ammonia-oxidizing marine archaeon. Nature 2005;437:543-6.

Khanna PK, Raison RJ, Falkiner RA. Chemical properties of ash derived from Eucalyptus litter and its effects on forest soils. For Ecol Manag 1994;66:107-25.

Knicker H. How does fire affect the nature and stability of soil organic nitrogen and carbon? A review. Biogeochemistry 2007;85:91-118.

Kumar S, Nei M, Dudley J, Tamura K. MEGA: a biologist-centric software for evolutionary analysis of DNA and protein sequences. Brief Bioinform 2008;9:299-306.

Leininger S, Urich T, Schloter M, Schwark L, Qi J, Nicol GW, et al. Archaea predominate among ammonia-oxidizing prokaryotes in soils. Nature 2006;442:806-9.

Long $\mathrm{X}$, Chen $\mathrm{C}, \mathrm{Xu} \mathrm{Z}$, Oren $\mathrm{R}, \mathrm{He} \mathrm{J}-\mathrm{Z}$. Abundance and community structure of ammonia-oxidizing bacteria and archaea in a temperate forest ecosystem under ten-years elevated CO2. Soil Biol Biochem 2012;46:163-71.

Mabuhay JA, Isagi Y, Nakagoshi N. Microbial biomass, abundance and community diversity determined by terminal restriction fragment length polymorphism analysis in soil at varying periods after occurrence of forest fire. Microbes Environ 2004;19: 154-62.

Mabuhay JA, Nakagoshi N, Horikoshi T. Microbial biomass and abundance after forest fire in pine forests in Japan. Ecol Res 2003;18:431-41.

Matson PA, Vitousek PM, Chapin MC. Principles of terrestrial ecosystem ecology. New York, NY: Springer; 2011.

Neary DG, Klopatek CC, DeBano LF, Ffolliott PF. Fire effects on belowground sustainability: a review and synthesis. For Ecol Manag 1999;122:51-71.

Niboyet A, Brown JR, Dijkstra P, Blankinship JC, Leadley PW, Le Roux X, et al. Globa change could amplify fire effects on soil greenhouse gas emissions. PLoS One 2011;6:e20105.

Nugroho RA, Röling WFM, Laverman AM, Zoomer HR, Verhoef HA. Presence of Nitrosospira cluster 2 bacteria corresponds to $\mathrm{N}$ transformation rates in nine acid Scots pine forest soils. FEMS Microbiol Ecol 2005;53:473-81.

O'Sullivan CA, Wakelin SA, Fillery IRP, Gregg AL, Roper MM. Archaeal ammonia oxidisers are abundant in acidic, coarse-textured Australian soils. Soil Res 2012;49:715-24.

Oksanen J, Blanchet G, Kindt R, Legendre P, O'Hara RG, Simpson GL, et al. Vegan: community ecology package. $\mathrm{R}$ package version $1.17-1 ; 2010$.

Orians GH, Milewski AV. Ecology of Australia: the effects of nutrient-poor soils and intense fires. Biol Rev Camb Philos Soc 2007;82:393-423.

Pietikäinen J, Fritze H. Clear-cutting and prescribed burning in coniferous forest: comparison of effects on soil fungal and total microbial biomass, respiration activity and nitrification. Soil Biol Biochem 1995;27:101-9.

Sahan E, Muyzer G. Diversity and spatio-temporal distribution of ammonia-oxidizing Archaea and Bacteria in sediments of the Westerschelde estuary. FEMS Microbio Ecol 2008;64:175-86.

Smith NR, Kishchuk BE, Mohn WW. Effects of wildfire and harvest disturbances on forest soil bacterial communities. Appl Environ Microbiol 2008;74:216-24.

Sterner RW, Elser JJ. Ecological stoichiometry: the biology of elements from molecules to the biosphere. Princeton Univ Pr; 2002.

Sun YJ, Xing W, Li JP, Lu YQ, Zuo JE. Microbial community in granules from a high-rate EGSB reactor. Prikl Biokhim Mikrobiol 2009;45:593-8.

Tourna M, Freitag TE, Nicol GW, Prosser JI. Growth, activity and temperature responses of ammonia-oxidizing archaea and bacteria in soil microcosms. Environ Microbiol 2008;10:1357-64.

Ulery AL, Graham RC, Amrhein C. Wood-ash composition and soil pH following intense burning. Soil Sci 1993:156:358-64.

Urakawa H, Tajima Y, Numata Y, Tsuneda S. Low temperature decreases the phylogenetic diversity of ammonia-oxidizing archaea and bacteria in aquarium biofiltration systems. Appl Environ Microbiol 2008;74:894-900.

Vance ED, Brookes PC, Jenkinsen DS. An extraction method for measuring soil microbial biomass C. Soil Biol Biochem 1987;19:703-7.

Vázquez FJ, Acea MJ, Carballas T. Soil microbial populations after wildfire; 199393-103.

Wardle DA, Nilsson MC, Zackrisson O. Fire-derived charcoal causes loss of forest humus. Science 2008;320:629.

Westerling AL, Hidalgo HG, Cayan DR, Swetnam TW. Warming and earlier spring increase western US forest wildfire activity. Science 2006;313:940-3.

Yeager CM, Northup DE, Grow CC, Barns SM, Kuske CR. Changes in nitrogen-fixing and ammonia-oxidizing bacterial communities in soil of a mixed conifer forest after wildfire. Appl Environ Microbiol 2005;71:2713-22.

Zhang T, Ye L, Tong AHY, Shao MF, Lok S. Ammonia-oxidizing archaea and ammoniaoxidizing bacteria in six full-scale wastewater treatment bioreactors. Appl Microbiol Biotechnol 2011;91:1215-25. 